\title{
IMPLEMENTASI PERANGKAT PEMBELAJARAN BERKARAKTER BERORIENTASI MODEL PEMBELAJARAN PEMAKNAAN UNTUK MELATIHKAN SIKAP MORAL SISWA
}

\author{
Agustina Pertiwiningrum ${ }^{1)}$ \\ Muslimin Ibrahim 2) \\ Yuni Sri Rahayu ${ }^{2}$ \\ ${ }^{1)}$ Guru Mata Pelajaran Biologi SMA Negeri 18 Surabaya \\ ${ }^{2)}$ Dosen Program Studi Pendidikan Sains, Program Pascasarjana Universitas Negeri Surabaya \\ e-mail: ')agustinbio@yahoo.com
}

\begin{abstract}
Implementation peripheral of study with character aim to overcome student moral decadence with moral attitude and improve result learn cognate at Human Reproductive System being use meaningful model study.The researcher use One Group PretestPostest Design during the implementation. The data were analized using quantitative and qualitative descriptive analysis. Result of implementation peripheral of study with character orient model study of meaningful in this research categorized very good. The implementation of the four lesson plans were very good. The 23 learning objectives were achieved. The achievement of moral attitude in moral knowing, moral feeling, and moral acting were very good. Suggestion the proposed is require to be developed by peripheral of study with character at different discussion fundamental to inculcate character values to educative participant.
\end{abstract}

Key words: Teaching materials with character, meaningful model study, moral attitude.

\begin{abstract}
Abstrak: Implementasi perangkat pembelajaran berkarakter bertujuan untuk mengatasi dekadensi moral siswa dengan membelajarakan sikap moral dan meningkatkan hasil belajar kognitif pada pokok bahasan Sistem Reproduksi Manusia menggunakan model pembelajaran pemaknaan. Rancangan penelitian yang dipakai adalah One Group Pretest-Postest Design dan hasil penelitian dianalisis menggunakan teknik analisis deskriptif kuantitatif dan kualitatif. Hasil implementasi perangkat pembelajaran berka rakter berorientasi model pembelajaran pemaknaan dalam penelitian ini dikategorikan sangat baik. Keterlaksanaan rata-rata dari keempat RPP dikategorikan sangat baik. Ketuntasan dari 23 Tujuan Pembelajaran tercapai. Hasil belajar kognitif mencapai 95\% tuntas. Hasil belajar sikap moral pada aspek pengetahuan moral (moral knowing), perasaan moral (moral feeling), dan tindakan moral (moral acting) mencapai 100\% tuntas dengan kategori sangat baik. Saran yang diusulkan adalah perlu dikembangkan perangkat pembelajaran berkarakter pada pokok bahasan yang berbeda untuk menanamkan nilai-nilai karakter kepada peserta didik.
\end{abstract}

Kata Kunci: Model pembelajaran pemaknaan, perangkat pembelajaran berkarakter, sikap moral.

\section{PENDAHULUAN}

Amanat Undang Undang Nomor 20 tahun 2003 tentang Sistem Pendidikan Nasional pasal 3 menjelaskan bahwa Pendidikan Nasional berfungsi mengembangkan kemampuan dan membentuk watak serta peradaban bangsa yang bermartabat dalam rangka mencerdaskan kehidupan bangsa, bertujuan untuk berkembangnya potensi peserta didik agar menjadi manusia yang beriman dan bertakwa kepada Tuhan Yang Maha Esa, peduli, sehat, berilmu, cakap, kreatif, mandiri, dan menjadi warga negara yang demokratis serta bertanggung jawab.

Ki Hajar Dewantara dan Mahatma Gandhi memperingatkan bahwa salah satu dari tujuh dosa fatal adalah 'education without character'. Begitu juga King mengatakan 'intellegence plus character ... that is the goal of true education' (Bier, 2005). Roosevelt juga mengingatkan bahwa 'to educate a person in mind and not in morals is to educate a menace to society' (Bassiouny et al.,2008).
Kebijakan nasional pembangunan karakter bangsa disusun sebagai pelaksanaan amanat UU RI No. 17 Tahun 2007 tentang Rencana Pembangunan Jangka Panjang Nasional Tahun 2005 - 2025. Keberhasilan pembangunan karakter bangsa ditandai dengan terwujudnya karakter bangsa yang tangguh, kompetitif, berakhlak mulia, bermoral, bertoleran, bergotong royong, patriotik, dinamis, berbudaya, dan berorientasi iptek berdasarkan Pancasila dan dijiwai oleh iman dan takwa kepada Tuhan Yang Maha Esa (Kemendiknas, 2010). Masalahnya sekarang mengapa terjadi peningkatan krisis nilai-nilai karakter bangsa, terutama krisis nilai moral pada generasi muda. Survei yang dilakukan Komisi Nasional Perlindungan Anak (Komnas PA) tahun 2008, dari 4.726 responden siswa SMP dan SMA di 17 kota besar sebanyak 62,7\% remaja SMP tidak perawan daN $21,2 \%$ remaja mengaku pernah aborsi. Perilaku seks bebas pada remaja tersebar di kota dan desa pada tingkat ekonomi kaya dan miskin. Dua tahun 
kemudian, survei yang dilakukan pada Mei 2010 terhadap remaja berusia 15-25 tahun dengan melakukan wawancara terhadap 663 responden di lima kota besar di Indonesia, Jabodetabek, Bandung, Yogyakarta, Surabaya dan Bali. Hasilnya $39 \%$ responden pernah melakukan hubungan seksual.

Hasil penelitian di Yogya dari 1.160 mahasiswa, $37 \%$ mengalami kehamilan sebelum menikah (http://hizbut- tahrir.or.id/2010/11/29/duh-bkkbn-catat-51remaja- jabodetabek-tidak-perawan/). Estimasi jumlah aborsi di Indonesia per tahun mencapai 2,4 juta jiwa, 800.000 di antaranya terjadi di kalangan remaja (http://hizbut- tahrir.or.id/2010/12/01/akibat-seks-bebas800-ribu- remaja-lakukan-aborsi/). Kasus homoseksual di Palembang terungkap pada April 2011. Celakanya tindakan ini dilakukan enam anak yang berumur 12-an tahun. Seorang siswi di kabupaten Malang menjadi sutradara sekaligus kameramen adegan seks dengan para pemain teman sekolahnya pada September 2011 (http://pendidikananakusiadini2.blogspot.com/2012/03/6 27-remaja-smp-tidak-perawan-i-survey.html). Data tersebut menunjukkan ada kecenderungan dekadensi moral mengalami peningkatan.

Fenomena peningkatan dekadensi moral juga terjadi di salah satu sekolah di Surabaya, seperti membolos, meninggalkan pelajaran, datang terlambat, merokok, mengambil uang dan HP teman, memalsu tanda tangan, mengganggu pelajaran, bertengkar, mengganti nilai raport, pacaran berlebihan, hamil diluar nikah, memotret teman yang sedang ganti pakaian di kamar mandi yang terekam pada Tabel 1.1 dokumen kenakalan siswa yang berhasil dicatat oleh BP-BK selama dua tahun terakhir antara tahun pelajaran 2010 samapai 2012.

Tabel 1 Kasus Kenakalan Siswa di salah satu SMA di Surabaya (Dokumen BP-BK)

\begin{tabular}{|c|l|c|c|}
\hline NO & \multicolumn{1}{|c|}{ Jenis Kegiatan } & $\mathbf{2 0 1 0 - 2 0 1 1}$ & $\mathbf{2 0 1 1 - 2 0 1 2}$ \\
\hline $\mathbf{1 .}$ & Pertengkaran & 12 kasus & 38 kasus \\
\hline $\mathbf{2 .}$ & Membolos & 17 kasus & 46 kasus \\
\hline $\mathbf{3 .}$ & Mengganggu proses pembelajaran & 15 kasus & 57 kasus \\
\hline $\mathbf{4 .}$ & Mencuri & 6 kasus & 24 kasus \\
\hline $\mathbf{5 .}$ & Pacaran berlebihan & 8 kasus & 29 kasus \\
\hline $\mathbf{6 .}$ & Hamil diluar nikah & 1 kasus & 3 kasus \\
\hline
\end{tabular}

Penelitian bermunculan untuk menjawab permasalahan ini. Hasil studi Berkowitz (2002) menyimpulkan bahwa ada peningkatan motivasi siswa dalam meraih prestasi akademik pada sekolah-sekolah yang menerapkan pendidikan karakter. Kelas-kelas yang secara komprehensif terlibat dalam pendidikan karakter menunjukkan adanya penurunan drastis pada perilaku negative peserta didik yang dapat menghambat keberhasilan akademik. Keberhasilan seseorang di masyarakat $80 \%$ dipengaruhi oleh kecerdasan emosi dan hanya 20\% ditentukan oleh kecerdasan otak (IQ) (Goleman,
1995). Anak-anak yang mempunyai masalah dalam kecerdasan emosinya, akan mengalami kesulitan belajar, tidak mudah bergaul dan tidak dapat mengontrol emosinya. Anak-anak yang bermasalah ini sudah dapat dilihat sejak usia pra-sekolah, dan kalau tidak ditangani akan terbawa sampai usia dewasa. Sebaliknya para remaja yang berkarakter akan terhindar dari masalah- masalah umum yang dihadapi oleh remaja seperti kenakalan, tawuran, narkoba, miras, perilaku seks bebas, dan sebagainya.

Serupa dengan hasil temuan dalam penelitian tersebut, menurut banyak pakar pendidikan karakter adalah obat ampuh bagi kemerosotan moral (Beachum and McCray, 2002). Fakta merosotnya dekadensi moral yang cenderung meningkat dan hasil penelitian tentang pendidikan karakter membuat peneliti tertarik untuk mengimplementasikan perangkat pembelajaran berkarakter yang dapat membelajarkan sikap moral sebagai upaya untuk memperbaiki karakter dan meminimalisir kemerosotan moral di kalangan pelajar. Nilai yang dipilih untuk dikembangkan merupakan nilai- nilai yang diharapkan mampu membentuk siswa berakhlak mulia (akhlakul karimah) melalui internalisasi nilai tersebut dalam diri siswa dan terejawantahkan dalam sikap dan perbuatan yang secara otomatis terpatri dalam jiwa tiap-tiap siswa.

Model pembelajaran pemaknaan pada mata pelajaran biologi diharapkan dapat digunakan untuk meningkatkan sikap moral siswa. Biologi sebagai salah satu cabang dari Ilmu Pengetahuan Alam (IPA) terdapat berbagai gejala/ fenomena yang amat menarik dan berpotensi untuk menjadi model sikap moral. Untuk mengajarkan sikap moral membutuhkan contoh dan teladan, tentang bagaimana sikap moral itu dilakukan. Alam menyediakan model yang dapat ditiru oleh siswa jika guru membantu siswa untuk menangkap makna. Internalisasi dilakukan terhadap gejala/ fakta/ konsep tertentu dan mengaitkannya dengan sikap moral yang terdapat di dalam norma-norma kehidupan sehari-hari.

Hasil penelitian penerapan model pembelajaran pemaknaan pada bidang studi IPA di beberapa SD dan SMP menunjukkan bahwa implementasi model pembelajaran pemaknaan mampu menumbuhkan sikap positif, budi pekerti dan akhlak mulia (Ibrahim, 2008). Sementara Habibi (2009) melakukan penelitian di SMA pada mata pelajaran biologi, memperoleh hasil bahwa model pembelajaran pemaknaan dapat mengajarkan kemampuan berpikir kritis dan sensitivitas moral. Begitu juga Agustina (2010), hasil penelitiannya menyimpulkan bahwa implementasi perangkat pembelajaran fisika berorientasi model pembelajaran pemaknaan mampu mengajarkan kecakapan emosional dan meningkatkan hasil belajar kognitif siswa SMP. Hasil penelitian Sumarni (2011) 
menyatakan bahwa penerapan model pembelajaran pemaknaan mampu mengembangkan karakter siswa SMA pada mata pelajaran kimia.

Merujuk pada UU nomor 20 tahun 2003 tentang tujuan pendidikan nasional, pendapat tokoh pendidikan dunia, tujuan pendidikan biologi SMA, grand disain pendidikan karakter dan berbagai hasil penelitian tentang penanaman nilai karakter kepada peserta didik, maka peneliti ingin melakukan penelitian implementasi perangkat pembelajaran berkarakter berorientasi model pembelajaran pemaknaan pada pokok bahasan Sistem Reproduksi Manusia untuk membelajarkan sikap moral.

\section{METODE}

Subyek penelitian adalah siswa SMA Negeri 19 Surabaya kelas XI IPA-1 sebanyak 36 orang. Implementasi perangkat pembelajaran berkarakter berorientasi model pembelajaran pemaknaan dilakukan pada semester genap tahun pelajaran 2012/2013 mulai tanggal 20 sampai 30 Mei 2013. Dalam seminggu dilakukan PBM dengan 3 kali tatap muka. KBM memerlukan waktu 4 kali tatap muka selain pretest dan postest. Implementasi perangkat pembelajaran berkarakter menggunakan rancangan pre-eksperiment One Group Pretest-Postest Design. Observasi yang dilakukan sebelum eksperimen (O1) disebut Pretest dan observasi sesudah eksperimen $(\mathrm{O} 2)$ disebut Postest. Penelitian uji coba ini menggunakan rancangan penelitian sebagai berikut (Arikunto, 1998):

\section{$01 \times 02$}

Keterangan :

$\mathrm{O} 1=\mathrm{Uji}$ awal

$\mathrm{X}=$ Implementasi perangkat pembelajaran

$\mathrm{O} 2=\mathrm{Uji}$ akhir

Instrumen penelitian yang digunakan terdiri dari:

a. THB kognitif berupa soal pretest dan postest mencakup aspek CI- C5 berupa soal pilihan ganda, jawaban singkat, dan soal uraian.

b. THB Sikap moral meliputi Instrumen THB pengetahuan moral (moral knowing), THB perasaan moral (moral feeling), dan tindakan moral (moral acting). Tes diberikan sebelum pembelajaran (pretest) dan setelah pembelajaran (postest).

c. THB pengetahuan moral (moral knowing) berupa tes soal berbentuk pilihan ganda kognitif sensitivitas moral. Tiap-tiap option memiliki nilai sesuai dengan tingkat sensitivitas moral. Soal bergabung dengan Instrumen THB kognitif. Nilai yang diperoleh disesuaikan dengan rubrik penilaian tes pilihan ganda kognitif sensitivitas moral siswa dengan rubrik penilaian skala 1, 2, 3, dan 4 .

d. Instrumen THB perasaan moral (moral feeling) berupa laporan diri siswa yang ditulis berdasarkan penilain, visi dan misinya terhadap nilai-nilai moral yang dibelajarkan. Penilaian perasaan moral didasarkan pada rubrik penilaian perasaan moral (moral feeling) siswa pada instrumen Laporan Diri 1 dan Instrumen Laporan Diri 2, dengan skala penilaian 1, 2, 3 dan 4.

e. Instrumen THB tindakan moral (moral acting) berupa perilaku berkarakter dan keterampilan sosial siswa dalam kegiatan pembelajaran. Perilaku siswa diamati menggunakan lembar pengamatan tindakan moral (moral acting) pada pertemuan 3 dan 4. Perilaku yang direkam adalah sikap sedih, menangis, prihatin yang bisa dilihat dengan ciri meneteskan air mata, mata merah, menutup sebagian wajah, atau menundukkan kepala ketika vidio ditayangkan. Reaksi yang muncul setelah sikap moral dibelajarkan melalui pemaknaan konsep-konsep tertentu dicatat oleh pengamat. Penilaian tindakan moral diperoleh dari skor hasil pengamatan sensitivitas moral selama pembelajaran sesuai dengan rubrik penilaian pengamatan tindakan moral (moral acting) siswa, dengan skala 1, 2, 3, dan 4 .

Test disusun oleh peneliti berdasarkan petunjuk pengembangan tes dalam buku Assesmen Berkelanjutan, Konsep Dasar, Tahapan pengembangan dan Contoh (Ibrahim, 2005).

Selanjutnya hasil tes ini dianalisis tingkat ketercapaian tujuan pembelajaran, tingkat ketercapaian ketuntasan hasil belajar individual dan klasikal, serta reliabilitas dan sensitivitas butir soal.

\section{Teknik Pengumpulan Data}

Dalam penelitian ini, digunakan dua teknik pengumpulan data, yaitu:

\section{a. Pengamatan}

Pengamatan dilakukan terhadap proses kegiatan pembelajaran yang berlangsung, yaitu pengamatan terhadap keterlaksanaan RPP menggunakan Instrumen Lembar Pengamatan Keterlaksanaan RPP dan pengamatan terhadap tindakan moral (moral acting) selama kegiatan pembelajaran menggunakan Instrumen Lembar Pengamatan tindakan moral (moral acting).

\section{b. Pemberian Tes}

Tes Hasil Belajar kognitif dan sikap moral diberikan dua kali, sebelum rangkaian kegiatan pembelajaran dilaksanakan dan setelah selesai dilaksanakan, menggunakan perangkat tes yang serupa. Tes dilakukan untuk mengukur kemampuan akademik siswa menggunakan Instrumen THB Kognitif Soal Pilihan Ganda, Jawaban Singkat, dan Uraian, serta Instrumen THB pengetahuan moral (moral knowing), Instrumen THB Perasaan Moral (moral feeling). 


\section{Teknik Analisis Data}

Analisis data pada penelitian ini menggunakan teknik analisis deskriptif, baik secara kuantitatif maupun kualitatif.

\section{Analisis Keterlaksanaan RPP}

Keterlaksanaan RPP dianalisis menggunakan analisis deskriptif kualitatif. Data hasil pengamatan yang diberikan oleh dua orang pengamat menggunakan Instrumen keterlaksanaan RPP dicari persentase mengenai keterlaksanan tahapan-tahapan dalam RPP yang dilakukan guru selama proses pembelajaran berlangsung. Secara umum perhitungan persentase keterlaksanaan RPP (P) adalah sebagai berikut:

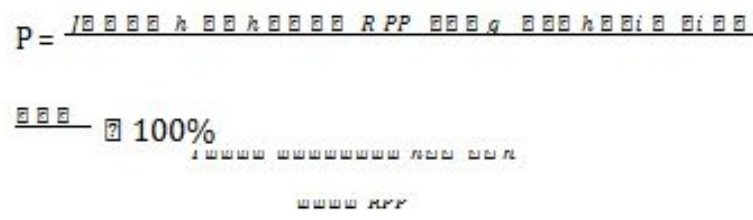

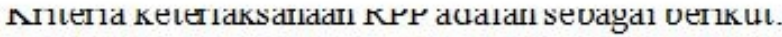

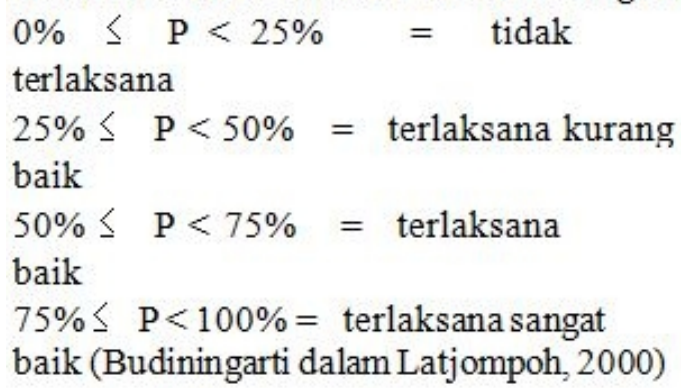

\section{Analisis Hasil Belajar Kognitif Siswa}

Analisis hasil belajar kognitif siswa diukur menggunakan tingkat ketuntasan individu dan klasikal. Tingkat ketuntasan individu ditetapkan minimal $\geq 73$ dan tingkat ketuntasan klasikal ditetapkan minimal $\geq 65$.

\section{Analisis Sikap Moral Siswa}

Analisis data sikap moral siswa terdiri dari pengetahuan moral, perasaan moral, dan tindakan moral. Pengetahuan moral diukur menggunakan tes pilihan ganda sensitivitas moral siswa, perasaan moral diukur menggunakan penilaian laporan diri siswa dan tindakan moral melalui pengamatan penilaian perilaku berkarakter dan keterampilan sosial. Nilai yang diperoleh dikonversi seperti Tabel 2 (Budiningarti dalam Latjompoh, 2000).

Tabel 2. Kategori Tingkat Sensitivitas Moral Siswa

\begin{tabular}{|c|c|c|}
\hline Skor & Kategori & Keterangan : \\
\hline $0,1-1,0$ & D & Perlu perbaikan \\
\hline $1,1-2,0$ & C & Menunjukkan kemajuan \\
\hline $2,1-3,0$ & B & Baik \\
\hline $3,1-4,0$ & A & Sangat Baik \\
\hline
\end{tabular}

\section{Reliabilitas Soal}

Reliabilitas merujuk pada satu pengertian bahwa suatu instrumen cukup dapat dipercaya untuk digunakan sebagai alat pengumpul data karena instrumen tersebut baik. Instrumen yang reliabel memiliki konsistensi skor yang dicapai oleh orang yang sama ketika mereka diuji ulang dengan tes yang sama pada kesempatan yang bebeda, atau pada kondisi pengujian yang berbeda. Karena jumlah soal pada tes hasil belajar kognitif ada soal pilihan ganda yang berjumlah ganjil, maka untuk mengetahui reliabilitas soal digunakan rumus KR-20 sebagai berikut (Ratumanan, 2006:35):

$$
\mathrm{r}_{11}=\frac{\mathrm{n}}{\mathrm{n}-1} \quad \frac{\mathrm{s}_{\mathrm{t}}{ }^{2}-\mathrm{piq}_{\mathrm{i}}}{\mathrm{S}^{+}}
$$

Keterangan:

r11 = Koefisien Reliabilitas

$\mathrm{n}$ = banyaknya butir soal

pi = proporsi banyak subyek yang menjawab

benar butir soal ke-i

$$
\text { qi = proporsi banyak subyek yang menjawab }
$$
salah butir soal ke-i

dimana:

$$
\mathrm{S}_{\mathrm{t}}^{2}=\frac{x_{\mathrm{t}}^{2}-}{\square}
$$

Keterangan:

$\begin{array}{lll}\mathrm{St}^{+} & = & \text {Varians skor total } \\ \mathrm{X}_{\mathrm{t}} & = & \text { Jumlah butir soal benar }\end{array}$

Sedangkan untuk mengetahui reliabilitas soal uraian digunakan rumus alpha.

$$
\begin{aligned}
& r_{11}=\alpha=\left(\frac{\mathrm{n}}{\mathrm{n}-1}\right)\left(1-\frac{\sum s_{i}^{2}}{S_{i}^{2}}\right) \\
& \sum S_{i}^{2}=\text { jumlah varians skor setiap item }
\end{aligned}
$$

Untuk mengetahui reliabilitas instrumen pengamatan tindakan moral, digunakan rumus alpha, hanya saja $n$ yang dimaksud adalah banyaknya belahan. Pada instrumen afektif yang dimaksud terdapat 4 belahan, mengacu pada banyaknya karakter yang diukur sikap tanggung jawab, peduli sosial, kemampuan bertanya dan berpendapat untuk pertemuan pertama dan kedua. Untuk pertemuan ketiga dan keempat terdapat 5 belahan yaitu sikap tanggung jawab, peduli sosial, kemampuan bertanya dan berpendapat dan tindakan moral.

Kriteria untuk menginterpretasi derajat reliabilitas digunakan Tabel 3.

Tabel 3 Kategori Derajad Reliabilitas Butir Soal

\begin{tabular}{|c|l|}
\hline Koefisien reliabilitas & \multicolumn{1}{c|}{ Penafsiran } \\
\hline $0,80 \leq \mathrm{r}$ & Derajat reliabilitas tinggi \\
\hline $0,40 \leq \mathrm{r}<0,80$ & Derajat reliabilitas sedang \\
\hline $\mathrm{r}<0,40$ & Derajat reliabilitas rendah \\
\hline
\end{tabular}




\section{Sensitivitas Butir Soal}

Soal dikatakan efektif jika dijawab dengan benar oleh lebih banyak siswa setelah berlangsung proses belajar mengajar. Untuk menghitung indeks sensitivitas pengaruh proses belajar mengajar (S) menggunakan rumus sebagai berikut (Grounlund, 1985):

$\mathrm{S}=\frac{R a-R b}{T}$

$\mathrm{S}=$ Sensitivitas butir soal

$\mathrm{Ra}=$ Jumlah siswa yang menjawab benar pada tes akhir

$\mathrm{Rb}=$ Jumlah siswa yang menjawab benar pada tes awal

$\mathrm{T}=$ Jumlah siswa yang mengikuti tes

Indeks butir soal yang efektif terdapat antara 0,00 sampai 1,00. Nilai positif yang lebih besar menyatakan butir soal yang lebih besar kepekaannya terhadap efek-efek pembelajaran. Butir soal yang mempunyai sensitivitas $\geq$ 0,30, maka butir soal tersebut peka terhadaP efek-efek pembelajaran (Aiken, 1997).

\section{HASIL DAN PEMBAHASAN}

\section{Tingkat Keterlaksanaan Pembelajaran}

Keterlaksanaan RPP adalah keterlaksanaan pembelajaran sesuai dengan sintak pada model pembelajaran pemaknaan. Sintak model pembelajaran pemaknaan meliputi 7 fase yaitu fase: mengorientasikan siswa pada masalah atau pertanyaan, fase 2: merancang proses pemecahan masalah, fase 3: membimbing penyelidikan atau membimbing tugas siswa, fase 4 : mengomunikasikan hasil, fase 5: negosiasi dan konfirmasi, fase 6: pemaknaan, dan fase 7: evaluasi dan refleksi.

Hasil rekapitulasi keterlaksanaan RPP pada tiaptiap pertemuan untuk masing-masing sintak dapat diilustrsikan pada Gambar 1 berikut.

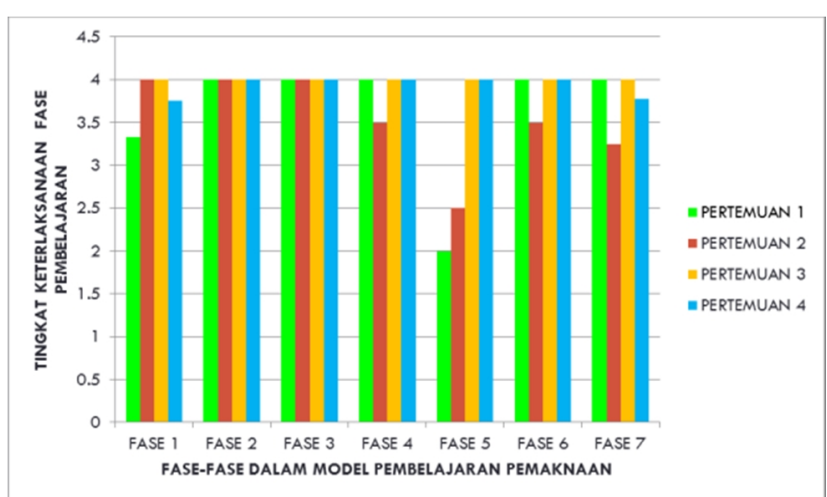

Gambar 1. Keterlaksanaan fase-fase dalam pembelajaran

Gambar 1menjelaskan bahwa fase-fase dalam model pembelajaran pemaknaan semua terlaksana dengan kategori baik hingga sangat baik, kecuali fase ke-5 pada pertemuan 1 dan 2. Hal ini disebabkan karena waktu yang tersedia sangat terbatas, siswa membutuhkan waktu lebih banyak dalam berdiskusi kelompok dan mempresentasikan hasil kerja kelompoknya. Guru masih harus mengingatkan siswa agar memanfaatkan waktu seefektif mungkin sehingga masing-masing fase dalam model pembelajaran akan terlaksana dengan baik. Kendala ini diatasi dengan memberikan tugas pengerjaan LKS di rumah sebelum didiskusikan dalam kelompoknya, sehingga waktu yang digunakan untuk pelaksanaan fase yang lain cukup proporsional. Hal ini terbukti pada pertemuan ke dua, ketiga, dan keempat fase 5 bisa dilaksankan dengan baik dan seimbang antar satu fase dengan fase yang lain.

\section{Hasil Belajar}

Berdasarkan tes hasil belajar kognitif dari 36 siswa terdapat 2 siswa yang tidak tuntas. Kedua siswa tersebut pernah tidak masuk sekali selama 4 kali tatap muka, sehingga mereka tidak menerima pembelajaran pada topik bahasan yang sudah disampaikan. Akibatnya nilai ketuntasan klasikalnya mencapai 95\%. Ketuntasan ini dikategorikan sangat baik karena berada di atas rata-rata yang sudah ditetapkan yaitu $65 \%$. Keberhasilan ini dicapai karena ada kerja sama yang baik antara siswa dengan guru, perangkat pembelajaran yang dipersiapkan telah mendapat validasi dengan kategori sangat baik. Perangkat pembelajaran meliputi silabus, RPP, Buku Ajar Siswa, LKS, Media Pembelajaran, dan THB. Sarana dan prasarana yang mendukung juga menentukan keberhasilan pembelajaran.

Nilai-nilai karakter yang diajarkan secara sistematis dalam model pendidikan holistik menggunakan metode knowing the good, feeling loving the good, dan acting the good (Leshnoff, 2007). Knowing the good bisa mudah diajarkan sebab pengetahuan bersifat kognitif saja. Setelah knowing the good harus ditumbuhkan feeling loving the good, yakni bagaimana merasakan dan mencintai kebajikan menjadi engine yang bisa membuat orang senantiasa mau berbuat sesuatu kebaikan. Sehingga tumbuh kesadaran bahwa, orang mau melakukan perilaku kebajikan karena dia cinta dengan perilaku kebajikan itu. Setelah terbiasa melakukan kebajikan, maka acting the good itu berubah menjadi kebiasaan (Suyanto, tanpa tahun). Sementara Narvaez dan Rest (1995), yang menyatakan bahwa sikap moral sebenarnya memiliki empat komponen yaitu: (1) sensitivitas moral, (2) keputusan moral, (3) motif moral, dan (4) Implementasi. Juga dalam Grand disain pendidikan karakter mengharapkan bahwa pendidikan hendaknya melatihkan olahpikir, olahhati, dan olahrasa.

Dengan mengadaptasi penanaman nilai karakter di atas, maka THB sikap moral dalam penelitian ini mengukur tiga aspek meliputi pengetahuan moral (moral knowing), perasaan moral (moral feeling), dan tindakan moral (moral 
acting), yang secara urut akan dijelaskan sebagai berikut:

\section{1) THB pengetahuan moral (moral knowing)}

Skor proporsi TP pengetahuan moral (moral knowing) dicapai sebesar 0,95 dari 6 TP telah mencapai ketuntasan. Siswa tidak terlalu sulit dalam mencapai pengetahuan moral karena sudah diajarkan sejak dalam kandungan. Sikap moral terkait konsep reproduksi manusia sudah dibelajarkan sejak kanak-kanak sampai jenjang pendidikan tinggi.

Masalah yang muncul sekarang adalah skor nilai pengetahuan moral yang tinggi mestinya diikuti oleh sikap moral yang terpuji, tetapi realitas di lapangan menunjukkan bahwa dekadensi moral semakin merajalela. Kuantitas dan kualitas kenakalan remaja sungguh sangat memprihatinkan. Hasil survei yang dilakukan Komisi Nasional Perlindungan Anak (Komnas PA) tahun 2008, dari 4.726 responden siswa SMP dan SMA di 17 kota besar sebanyak 62,7\% remaja SMP tidak perawan dan $21,2 \%$ remaja mengaku pernah aborsi. Perilaku seks bebas pada remaja tersebar di kota dan desa pada tingkat ekonomi kaya dan miskin. Survei pada Mei 2010 terhadap remaja berusia 15-25 tahun dengan melakukan wawancara terhadap 663 responden di lima kota besar di Indonesia, Jabodetabek, Bandung, Yogyakarta, Surabaya dan Bali. Hasilnya 39 \% responden pernah melakukan hubungan seksual. Pada April 2011 di Palembang terungkap kasus homoseksual. Celakanya tindakan ini dilakukan enam anak yang berumur 12an tahun. Pada September 2011, di Kabupaten Malang seorang siswi menjadi sutradara sekaligus kameramen adegan seks dengan para pemain teman sekolahnya. http://pendidikananakusiadini2. blogspot.com/2012/03/627-remaja-smp-tidak-perawan-isurvey.html. Bagaimana dengan kasus anak menelantarkan orang tuanya, ibu membunuh janinya, pemerkosan, kekerasan dalam rumah tangga yang jumlahnya juga terus meningkat. Ternyata tidak ada hubungan yang signifikan antara pengetahuan moral dengan sikap moral. Hal ini sesuai dengan hasil penelitian pengembangan perangkat pembelajaran menggunakan model pembelajaran pemaknaan pada siswa SMP oleh Sartika (2010) yang menyatakan bahwa nilai sensitivitas moral tidak ada hubungannya dengan perolehan nilai kognitif siswa.

Fakta-fakta tersebut membuktikan bahwa tingginya pengetahuan moral tidak sebanding dengan sikap moralnya. Hal inilah yang tetap memotivasi peneliti untuk melanjutkan penelitiannya. Bagaimana metode/ cara/ tehnik yang tepat agar pengetahuan moral yang sudah baik ini mampu diejawantahkan dalam membentuk sikap moral. Usaha yang dilakukan peneliti adalah dengan mengembangkan perangkat pembelajaran berkarakter dimana salah satunya adalah pembelajaran yang mampu menyentuh emosi dan perasaaan siswa melalui implementasi perangkat pembelajaran berkarakter yang menekankan pada perbaikan sikap moral siswa.

Semua steam soal pengetahuan moral (moral knowing) diberikan pada siswa melalui pretest dan hasilnya dari 10 butir soal (soal nomor 16 - 25) semua sensitif hanya pada soal nomor 25 tidak sensitif. Soal nomor 25 tentang kasus aborsi, dari sini menjelaskan bahwa siswa sudah memahami cara, proses, hukum dan nilai aborsi, sehingga nilai pretest siswa sudah cukup tinggi.

\section{2) THB perasaan moral (moral feeling)}

Pada pretes perasaan moral rata-rata siswa mendapat skor 0,34. Dari sini peneliti terus melakukan modifikasi dan merevisi media pembelajaran untuk disesuaikan dengan kebutuhan meningkatkan sikap moral siswa terutama pada bagian perasaan moral. Peneliti melakukan browsing dari internet mencari vidio yang sesuai dengan pokok bahasan yang mampu menyentuh hati dan perasaan siswa terkait topik. Peneliti juga melakukan upaya agar tindakan moral yang ditunjukkan siswa sejalan dengan pengetahuan moralnya melalui model pembelajaran pemaknaan. Model pembelajaran yang mampu menyentuh hati dan perasaan siswa dengan meminta siswa untuk membuat laporan diri setelah membaca isi ,surat dari ayah bundae dan ,surat dari surga ${ }^{e e}$. Hal ini didukung oleh hasil penelitian Berkowiz (2002), untuk mengubah perilaku atau karakter baik, perlu dilakukan melalui pendekatan emosional/ perasaan.

Usaha peneliti tidak sia-sia. Setelah KBM pada pertemuan ketiga dan keempat tibalah saatnya hati dan perasaan siswa disentuh melalui "surat dari ayah bunda" dan "surat dari surga". Dua surat ini mampu membuat siswa berubah secara fisiologis dan emosional siswa yang dimunculkan dalam tindakan sedih, menangis, menanggapi isi surat tersebut. Sikap yang dimunculkan bergantung pada evaluasi atas pengetahuan dan penilaian yang diyakininya terkait konsep tertentu. Perubahan sikap moral adalah manifestasi dari pengetahuan dan perasaan moral serta nilai-nilai etika yang diyakininya (Carr, 2007).

Keberhasilan ini bisa dibuktikan dari skor rata-rata pada THB perasaan moral saat postes meningkat sebesar 0,66 menjadi 1,00. Nilai ini diperoleh melalui Laporan Diri siswa yang dituliskan setelah usai penayangan vidio. Keberhasilan THB perasaan moral (moral feeling) didukung oleh media pembelajaran yang dikembangkan peneliti untuk melatihkan sensitivitas moral. Selaras dengan pendapat Rest (1995) menyebutkan bahwa penting melakukan penanaman nilai-nilai moral pada setiap bidang kehidupan dalam diri seorang anak hingga ia dapat mandiri 
untuk belajar dan meningkatkan kesensitivan moralnya. Nilai moral berada dalam diri manusia sebagai suatu proses bertahap dan tidak berjalan dengan seketika. Nilai moral dapat menyatu dengan kepribadian manusia itu sendiri seiring dengan peristiwa yang dialaminya sebagai suatu proses belajar (Schulz, 2004).

Kepekaan siswa atas kasus kondisi orang tua yang telah lanjut usia yang khawatir dan cemas akan keberadaannya dalam lingkungan keluarga. Khawatir dan takut jika anak yang dilahirkan, disayang, dicintai, dirawat, dan dijaga ketika masih kecil tidak berkenan merawatnya ketika kondisi telah lanjut usia dan tak berdaya. Begitu juga tayangan vidio surat dari surga yang menjelaskan tentang bagaimana inginnya anak yang diaborsi hidup menemani ibu yang telah menggagalkan keinginannya dengan memaksa menggugurkan kandungannya. Ungkapan perasaan ayah bunda dan rintihan kesakitan calon bayi yang digagalkan hidupnya diharapkan mampu membangkitkan sensitivitas moral siswa. Hal ini terbukti bahwa nilai THB perasaan moral (moral feeling) dalam bentuk laporan diri mengalami peningkatan yang signifikan antara nilai pretes dengan postes yang dibuktikan dengan nilai sensitivitas butir soal yang tinggi.

\section{3) THB tindakan moral (moral acting)}

Hal yang perlu dicermati pada tindakan moral yang muncul dan diamati pada pertemuan ketiga dan keempat adalah banyak siswa yang tersentuh hatinya dengan menunjukkan sikap menangis, menutup sebagian wajah dengan tangan atau dengan kain jilbabnya. Menurut Sears (dalam Kurtines dan Gerwirtz, 1995) penelitian yang dilakukan pada tahun 1951 menyatakan bahwa perilaku moral manusia akan menjadi perilaku yang bersifat otomatis jika terus menerus diberikan penguatan (reinforcement).

Pengalaman belajar yang diberikan oleh peneliti, memungkinkan siswa untuk belajar memetik hikmah dari fakta, konsep yang dipelajari dikaitkan dengan kehidupan nyata untuk membentuk akhlak mulia, selain tetap mampu meningkatkan hasil belajar kognitifnya. Hal ini sesuai dengan pendapat Blazi (1995) yang menyatakan bahwa proses integrasi nilai-nilai moral selain terjadi melalui integrasi alami juga integrasi yang ditanamkan (cultivated). Model integrasi yang kedua inilah yang dicoba peneliti untuk diterapkan pada siswa dengan harapan sikap moral terbentuk. Selain itu Berkowiz dan Goleman (1995) mengatakan bahwa keberhasilan seseorang ditentukan hanya $20 \%$ oleh kecerdasan intelektualnya sedangkan $80 \%$ ditentukan oleh faktor lain. Salah satu faktor lain adalah kemampuan mengelola sikap (soft skill). Sikap muncul karena bisa diamati melalui tindakan, tindakan bermoral dapat terjadi jika siswa menguasai pengetahuan tentang moral, pengetahuan tentang moral dapat diimplementasikan dalam kehidupan sehari-hari jika perasaan moral berinternalisasi di dalam hati siswa sehingga melahirkan sikap moral atau akhlak mulia. Nilai moral yang telah menjadi bagian (terintegrasi) dalam perasaan ini disebut dengan identitas moral (moral identity). Konsep integrasi dikembangkan Blazi (1995), hampir mirip dengan konsep internalisasi Freud dalam Kurtines dan Gerwitz, 1995.

Suasana kelas yang mendukung dengan ruangan yang tertutup kelambu sehingga memungkinkan siswa untuk mengekspresikan gejolak emosi dan perasaannya atas tayangan vidio. Setelah selesai menyaksikan vidio, peneliti mencoba mengingatkan kembali tentang sikap kita kepada kedua orang tua. Apakah sudah sesuai dengan yang orang tua harapkan, apakah kita sayang kepada kedua orang tua kita? Tidak pernahkah kita membentak mereka dan senantiasa menuruti apa perintah mereka? Dan Apakah kita telah menjadi anak yang berbakti kepada kedua orang tua ataukah anak yang durhaka kepada mereka. Apakah kita tidak pernah menyakiti mereka? Ketika peneliti menyampaikan kalimat-kalimat tersebut ada siswa yang semakin menundukkan kepalanya dan menangis teringat dan menyesali apa yang telah dilakukannya kepada kedua orang tua mereka.

Meskipun banyak hasil penelitian mengatakan bahwa perilaku atau konatif sebagai tindakan moral tidak selalu menggambarkan sikap moral yang diyakininya. Sikap moral sangat ditentukan oleh latar belakang dan tujuan serta banyak faktor eksternal yang mempengaruhinya sehingga pengetahuan moral sering tidak selaras dengan perasaan dan tindakan moral yang ketiganya membentuk sikap moral. Tetapi banyak ahli juga mengatakan bahwa pada diri seseorang itu ada kecenderungan untuk mencapai keseimbangan antara pengetahuan, perasaan, dan tindakan yang akan membentuk sikap. Hal inilah yang peneliti coba untuk kembangkan bagaimana dunia pendidikan mampu membentuk watak dan karakter peserta didik melalui sensitivitas moral. Artinya perubahan sikap moral harus terus dibelajarkan dengan mengolaborasikan tiga aspek yang menentukan terjadinya proses internalisasi dalam diri siswa. Perubahan tingkah laku bisa dilakukan melalui proses belajar (Schulz, 2001).

Hubungan antara pengetahuan, perasaan, dan tindakan moral bisa dilihat pada gambar 3 korelasi nilai aspek sikap moral. Ada korelasi teratur antara nilai pada moral knowing, moral feeling, moral acting. Hal ini sejalan dengan pendapat Azwar (2000) bahawa antara sikap dengan perilaku terjadi hubungan konsistensi. Sementara Breckler \& wiggins mengatakan bahwa sikap yang diperoleh lewat pengalaman akan menimbulkan pengaruh langsung terhadap perilaku tersebut. Perilaku tersebut akan 
direalisasikan hanya apabila kondisi dan situasi memungkinkan. Hal inilah yang menjadi kendala dalam mengukur validitas sikap. Apa yang dimunculkan oleh perilaku belum tentu menggambarkan sikap (moral knowing, moral feeling, moral acting) yang diyakininya. Meskipun mengukur sikap sulit dilakukan dengan mengondisikan suasana belajar diharapkan tindakan yang direkam mampu menggambarkan sikap yang diyakini siswa.

Nilai ketercapaian semua indikator semua dinyatakan tuntas. Indikator nomor 12 dituntaskan dengan mengubah bentuk tugas yang diberikan pada LKS sehingga konsep penting dapat dikuasai siswa dan animasi perkembangan embrio bisa dipakai untuk memperkuat konsep.

\section{Analisis hasil belajar siswa}

Ketuntasan individu dan klasikal

Secara individu, seorang siswa dapat dikatakan tuntas apabila nilai yang diperoleh sama atau melampaui KKM yang telah ditetapkan yaitu $\geq 73 \%$ dan ketuntasan klasikal $\geq 65 \%$.

\section{Ketuntasan tujuan pembelajaran}

Tujuan pembelajaran dikatakan tuntas apabila persentase siswa yang mencapai tujuan pembelajaran $\geq$ $80 \%$.

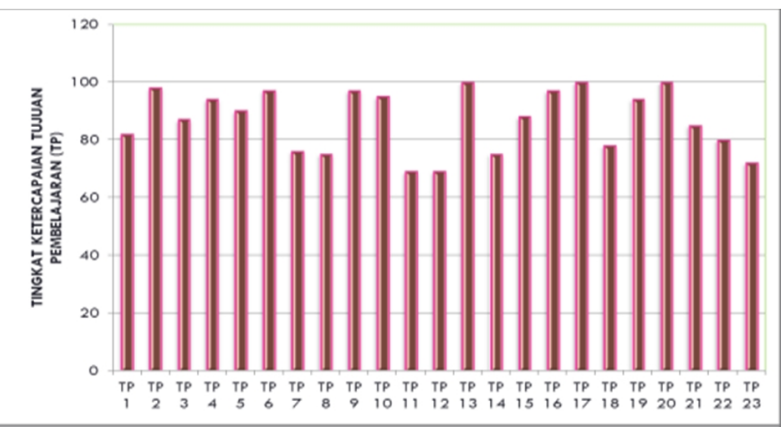

Gambar 2 Grafik ketuntasan tujuan pembelajaran

Ketuntasan THB Kognitif PG untuk TP nomor 1, 4, 7, 8, 11, dan 12 semua tuntas. Ketuntasan THB Kognitif jawaban singkat dan uraian untuk TP nomor 3, 5, 14, 15, dan 19 semua tuntas. Hal ini menunjukkan bahwa sintak dalam model pembelajaran terlaksana dengan baik dan materi yang dibelajarkan telah dikuasai siswa dengan baik pula. Hal ini tercapai karena guru sudah terlatih mengendalikan siswa dan menguasai sintaks model pembelajaran pemaknaan serta strategi dalam menangani siswa yang mengalami kesulitan belajar, baik ketika mengerjakan LKS maupun saat presentasi. Guru juga mampu memotivasi siswa agar tiap-tiap siswa berperan dalam pembelajaran dengan bertanya atau berpendapat. Tugas LKS dan presentasi menjadi tanggung jawab kelompok. Tiap-tiap siswa harus menguasai materi yang sedang dibelajarkan, sehingga muncul tanggung jawab siswa atas tugas yang diberikan guru. Menurut teori Edgar Dale semakin banyak alat indera yang terlibat dalam pembelajaran maka semakin kuat konsep disimpan dalam ingatan siswa.

Sensitivitas 15 butir soal THB kognitif PG dan 5 butir soal jawaban singkat dan uraian semua sensitif. Hal ini disebabkan karena semua soal telah disusun sesuai dengan peraturan dalam penulisan soal PG yang baik dan telah ditelaah serta divalidasi oleh tiga pakar pengembangan dan telah mengalami revisi.

THB kognitif jawaban singkat dan uraian, dari 5 tujuan pembelajaran semua tuntas, butir soal sensitif dan reliabel. Semua dinyatakan valid tanpa revisi. Karena soal yang dibuat dengan perintah, gambar, arahan jelas dan siswa betul-betul tahu dan paham konsep yang dipelajari. Hal ini terlihat dari sensitivitas butir soal yang tinggi. Artinya soal peka terhadap efek pembelajaran. Hal ini menggambarkan bahwa KBM yang direncanakan dalam RPP sudah berjalan dengan baik yang berdampak pada baiknya hasil pembelajaran dengan tingkat ketuntasan yang tinggi. Hal ini sesuai dengan pendapat Sudjana (2001) bahwa faktor utama yang dapat mempengaruhi hasil belajar siswa ada dua, yaitu faktor dalam (intern) dari diri siswa itu sendiri dan faktor luar (ekstern) yang berasal dari lingkungannya.

\section{ANALISIS HUBUNGAN ANTARA NILAI KOGNITIF DENGAN SIKAP MORAL}

Hasil analisis hubungan antara nilai kognitif dengan nilai yang dicapai pada sikap moral secara umum adalah konsisten. Artinya ada kecenderungan jika nilai kognitifnya baik maka akan diiuti oleh sikap moral yang baik. Tetapi ada perkecualian pada siswa dengan nomor presensi 4 dan 11. Keduanya nilai kognitif tidak tuntas tetapi nilai pada sikap moral tuntas. Pada kasus kedua siswa ini dapat dijelaskan sebagai berikut. Siswa dengan nomor presensi 4 tidak mengikuti pelajaran pada pertemuan pertama karena kecelakaan kecil sehingga dia datang terlambat. Sedangkan untuk siswa dengan nomor presensi 11 tidk masuk pada pertemuan kedua karena sakit. Pada pertemuan pertama dan kedua kegiatan pembelajaran sarat akan pengetahuan dan konsep tentang sistem reproduksi manusia. Karena pada kedua pertemuan ini mereka tidak bisa mengikuti pembelajaran akhirnya nilai kognitifnya tidak tuntas. Pada pertemuan ketiga dan keempat keduanya masuk dan mengikuti pembelajaran yang menekankan tentang sikap moral. Sehingga nilai yang mereka peroleh sangat memuaskan. Hal inilah yang menyebabkan konsistensi nilai kognitif tidak selaras dengan nilai pada sikap moral yang diperoleh kedua siswa tersebut. 
Hasil analisis konsistensi nilai kognitif dengan nilai sikap moral siswa diilustrasikan pada Gambar 3 dan 4 berikut ini:

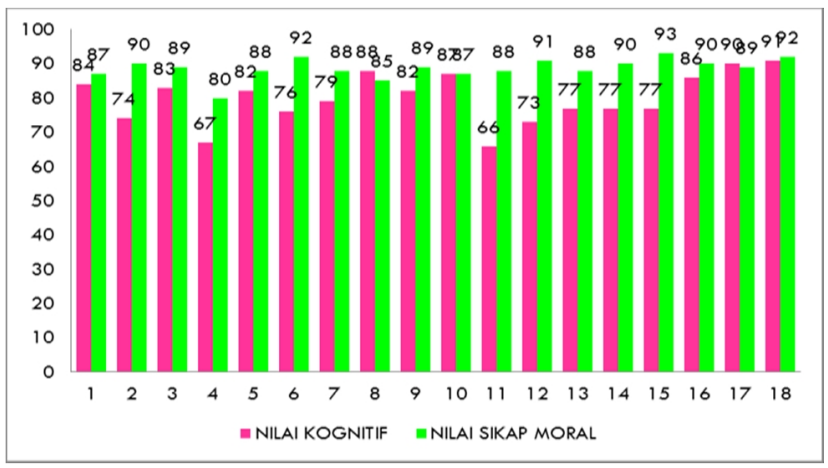

Gambar 3 Grafik hubungan antara nilai kognitif dengan sikap moral masing-masing siswa

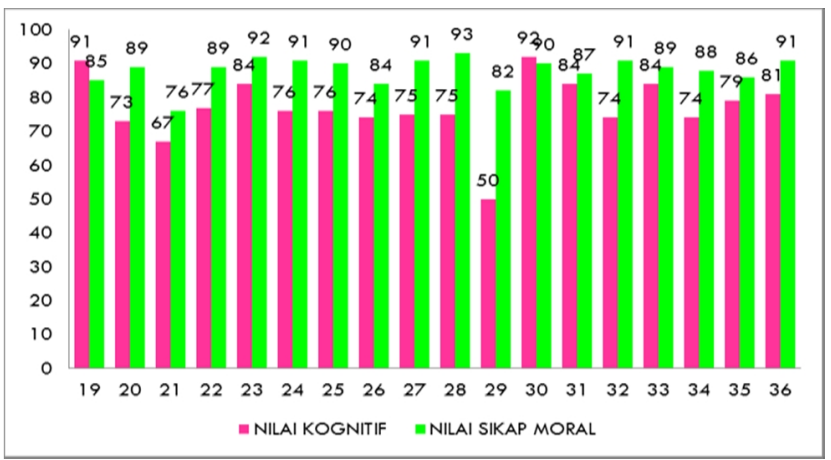

Gambar 4 Lanjutan Grafik hubungan antara nilai kognitif dengan sikap moral masing-masing siswa

Hubungan antara ketercapaian pengetahuan kognitif dengan sikap moral pada dapat diilustrasikan melalui grafik pada Gambar 3 dan 4. Setelah konsep dibelajarkan dapat disimpulkan bahwa peningkatan nilai pengetahuan kognitif sejalan dengan sikap moral. Nilai tes hasil belajar kognitif siswa sebanding dengan nilai tes hasil belajar sensitivitas moral. Begitu juga pada hasil belajar sensitivitas moral bahwa ada kecenderungan nilai pengetahuan moral sebanding dengan nilai pada perasaan moral dan tindakan moral. Tindakan moral siswa yang mendapat nilai baik mencerminkan nilai pengetahuan moral dan perasaan moral yang juga baik. Hal ini sesuai dengan postulat konsistensi yang dikemukakan oleh Azwar (2000) yang menyatakan bahwa sikap moral merupakan hasil evaluasi dari pengetahuan moral, perasaan moral dan tindakan moral. Seseorang akan bersikap baik jika dia mengetahui pengetahuan tentang kebaikan dan hatinya peka akan nila-nilai baik dan dia akan mewujudkan kebaikan itu dalam perilaku kesehariannya dalam bentuk sikap moral.

\section{Sensitivitas Butir Soal}

Berdasarkan hasil perhitungan sensitivitas butir soal dari 30 butir soal hanya satu yang tidak sensitif yaitu soal nomor 25. Rata-rata sensitivitas dari ketigapuluh soal yang dikembangkan sebesar 0,42 .

\section{Reliabilitas THB Kognitif dan Sikap Moral}

Reliabilitas THB kognitif 0,48 untuk soal PG, 0,52 untuk soal jawaban singkat dan uraian. Reliabilitas THB sikap moral 0,78 untuk soal pengetahuan moral, 0,57 untuk soal perasaan moral, dan 0,83 untuk soal tindakan moral.

\section{SIMPULAN}

Berdasarkan analisis data penelitian, dapat disimpulkan bahwa keterlaksanaan perangkat pembelajaran dari keempat RPP yang telah diimplementasikan dikategorikan sangat baik dan reliabilitas instrumen yang bersifat reliabel. Sikap Moral siswa pada aspek pengetahuan moral (moral knowing), perasaan moral (moral feeling), dan tindakan moral (moral acting) semua dinyatakan tuntas. Hasil uji awal dan uji akhir terdapat peningkatan proporsi jawaban benar siswa untuk THB kognitif dan THB sikap moral. Tujuan Pembelajaran yang ingin dicapai sebanyak 23 semua tunas.

Untuk lebih sempurnanya perangkat pembelajaran yang dikembangkan dalam rangka melatihkan sensitivitas moral, perlu dilakukan penelitian serupa pada pokok bahasan yang sama. Perlu dilakukan penelitian serupa untuk mengubah karakter siswa menjadi lebih positif dengan melatihkan sensitivitas moral menggunakan model pembelajaran pemaknaan.Berdasarkan hasil analisis data yang kemudian dideskripsikan pada diskusi hasil penelitian, maka dapat dibuat kesimpulan bahwa perangkat pembelajaran model inkuiri terbimbing efektif sebagai upaya meningkatkan hasil belajar siswa SMA pada materi listrik dinamis.

\section{REFERENSI}

Aiken, L.R. 1997. Psychological Testing and Assessment. Ninth Edition. New York: McGraw Hill Companies.

Anonim. 2010. Kenakalan Remaja. http://hizbuttahrir.or.id/2010/11/29/duh-bkkbn-catat-51-remajajabodetabek-tidak-perawan/ (diakses 29-03-2013).

Arikunto, S. 1998. Prosedur Penelitian, suatu Pendekatan Praktek. Jakarta: PT. Rineka Cipta.

Azwar, S. 2000. Sikap Manusia, Teori dan Pengukurannya. Yogyakarta: Pustaka Pelajar.

Bassiouny, N. E., Taher, A., dan Aish, E. M. A. 2008. "The Importance Character Education for Tweens as Consumers". Journals of Research in Character Education, Vol. 6, No. 2, pp. 37-61.

Beachum, F. D, dan C. R. McCray, 2002. Changes and Transformation in the Philosophy of Character Education in the 20th Century, Milawaukee: University of Wisconsin. 
Berkowitz, M, W. 2002. Understanding effective Character Education, Ontario: Literacy and Numeracy Secretariat Capacity Building Series.

Bier, M. C., \& Berkowitz, M. W. 2005. "What Work in Character Education". ProQuest Education Journals. Vol. 34, No. 2, pp. 7-13.

Blazi, A. 1995. Moral Integration. Dalam Kurtines, W. M. dan Gerwirtz, J. L. Moral Development, an Introduction. Needham Heights: A Simons and Schuster Company.

Carr, D. 2007. "Moralized Psychology or Psychologized Morality? Ethics And Psychology. Educational Theory" ProQuest Education Journals. Vol. 57, No. 4, pp. 389-402.

Goleman, D. 1995. Emotional Intellegence.New York: Bantam Books.

Grounlund, N.E. 1985. Constructing Achievement Test. Third Edition. New Jersey: Prencite-Hall.

Ibrahim, M. 2005. Asesmen Berkelanjutan Konsep Dasar, Tahapan Pengembangan dan Contoh. Surabaya: Unesa University Press.

Ibrahim, M. 2008. Model Pembelajaran IPA Inovatif Melalui Pemaknaan. Jakarta: Tim Peneliti Balitbang. Kemendiknas. 2010. Pengembangan Pendidikan Budaya dan Karakter Bangsa Pedoman Sekolah. Jakarta: Balitbang Puskur.

Kurtines, W. M. dan Gerwirtz, J. L., 1995. Moral Development, an Introduction. Needham Heights:

A. Simons and Schuster Company.

Leshnoff, S. K. 2007. "Since When Does Art Contrute to Character Development in Education?" Journals of Cultural Research in Art Education. Vol. 1, No. 25, pp. 143-153.

Lickona, T. 1991. Educating for Character, New York: Bantam Books.

Lotjompoh, M. 2000. "Pengembangan Perangkat Pembelajaran

Biologi SMU Pokok Bahasan Sistem Koordinasi Berorientasi Strategi Belajar (Rehearsal, Elaborasi, Organisasi)". Tesis. Tidak Dipublikasikan. Surabaya: Universitas Negeri Surabaya.

Nucci, L. P. dan D. Narvaez, 2008. Handbool of Moral and Character Education, New York: Routledge

Pemerintah Republik Indonesia, 2010. Pembangunan Karakter Bangsa Tahun 2010-2025.

Pusat Kurikulum dan Perbukuan, 2010. Pedoman Pelaksanaan Pendidikan Karakter, Jakarta: Pusat Kurikulum dan Perbukuan, Badan Penelitian dan Pengembangan Kementrian Pendidikan Nasional.

Qureshi. 2004. Instructional Design Models. [Online]. Tersedia:http://web2.uwindsor.ca/courses/edfac/morto n/instructio naldesign.htm [22 Agustus 2010].
Ratumanan, T.G dan T, Laurens. 2003. Evaluasi Hasil Belajar. Surabaya: Unesa University Press.

Rest, J. 1995. The Four Components of Acting Morally, dalam Kurtines, W. M. dan Gerwirtz, J. L., 1995. Moral Development, an Introduction. Needham Heights: A. Simons and Schuster Company.

Samani, M, 2011. Konsep dan Model Pendidikan Karakter.Bandung: Remaja Rosdakarya.

Sartika, S.B. 2010. "Pengembangan Perangkat Pembelajaran Fisika SMP melalui Model Pemaknaan untuk Meningkatkan Hasil Belajar dan Kecakapan Emosional Siswa". Tesis. Surabaya: Universitas Negeri Surabaya.

Schwartz, M. J. 2008. Effective Character Education, A Guidebook for Future Educator. Edisi pertama. McGraw-Hill.

Schulz, L. H., Barr, D. J., \& Selman, R. L., 2001. "The Value of Developmental Approach to Evaluating Character Development Programmes: An Outcome Study of Facing History and Ourselves" Journal of Moral Education, Vol. 30, No. 1, pp. 3-27.

Schulz, L. H. dan Selman, R. L., 2004. "The Development of Phychosocial Maturity in Young Children: A Measure for Evaluating Character Education Programs". ProQuest Education Journals. Vol. 2, No. 1, pp. 19-43.

Schulz, L. H., Selman, R. L., \& LaRusso, M. D., 2003. "The Assessment of Psychosocial Maturity in Children and Adolescents: Implications fot The Evaliation of School-based Character Education Programs". Journals of Research in Character Education, Vol. 1, No. 2, pp. 67-87.

Sudjana, N. dan Ibrahim. 2001. Penelitian dan Penilaian Pendidikan. Bandung: Sinar Baru Algensindo.

Suyanto. tanpa tahun. Urgensi Pendidikan Karakter.[OnLine].Tersedia: http://waskita mandiribk. wordpress.com/2010/06/02/urgensipendidikan-karakter/(19-11-2012)

http://pendidikananakusiadini2.blogspot.com/2012/03/627remaja-smp-tidak-perawan-i-survey.html (diakses pada tanggal 27 Juni 2013)

http://hizbut-tahrir.or.id/2010/11/29/duh-bkkbn-catat-51remaja-jabodetabek-tidak-perawan/

http://hizbut-tahrir.or.id/2010/12/01/akibat-seks-bebas-800ribu-remaja-lakukan-aborsi/

http://pendidikananakusiadini2.blogspot.com/2012/03/627remaja-smp-tidak-perawan-i-survey.html 